O AUTOR

Eduardo Luís Correia

Jornalista, gestor de comunicação pela ECA/ USP. Coordenador do Núcleo de Comunicação da Prefeitura de Santo André.

\title{
DESAFIOS DA COMUNICAÇÃO INSTITUCIONAL NA
}

\section{ADMINISTRAÇÃO PÚBLICA}

Projeto de comunicação estabelece diálogo entre a administração pública e a sociedade, privilegiando uma gestão comunicacional ampla e transparente

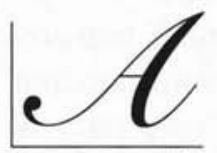

inflação de signos, conforme apontou o antropólogo italiano Massimo Canevacci $^{1}$, em meados da década de 80 , em seu estudo sobre a comunicação urbana na cidade de São Paulo, não apenas estabeleceu-se definitivamente nas modernas sociedades como ganhou amplitude neste quase início de novo século. Há, de fato, uma hiperinflação de signos travando uma disputa - muitas vezes silenciosa, outras nem tanto - por espaço no universo comunicacional das metrópoles.

No interior desta disputa, um ator peculiar - o município - deve procurar fazer-se ouvir. E por quê? Pelo simples motivo de que a administração pública municipal é a prestadora primeira de serviços básicos à população, geralmente para os estratos mais carentes e dependentes deles. Informar e orientar corretamente a comunidade sobre os serviços existentes é, antes de tudo, um dever do governo municipal. Em nome da otimização do uso dos equipamentos públicos, da prestação de contas e, por fim, da cidadania.

Fazer comunicação numa administração pública é uma ação das mais complexas e instigantes. São vários os fatores que tornam o processo comunicacional de uma gestão municipal uma atividade 
peculiar. Para a administração da cidade de Santo André, coração do ABC paulista, sedimentar a proposta de uma relação efetiva e dialógica com a comunidade é, provavelmente, seu principal desafio. Desafio que deve ser enfrentado pelo gestor de processos comunicacionais de modo decisivo.

\begin{tabular}{c}
\hline O papel do gestor de \\
comunicação é o de mediador, \\
propondo estratégias \\
comunicacionais que ouçam as \\
vozes de todas as partes \\
envolvidas no processo.
\end{tabular}

É nisso que a administração municipal, através do Núcleo de Comunicação que coordenamos, está apostando. A proposta de estabelecer como linha de trabalho a sedimentação de tal diálogo com a cidade vai ao encontro da posição do próprio governo municipal.

As dificuldades encontradas no estabelecimento de tal proposta são inúmeras, surgidas de várias frentes. Procuraremos abordar neste artigo algumas delas, as principais, mas longe de serem únicas. Antes disso é importante contextualizar Santo André no panorama comunicacional da região metropolitana de São Paulo.

O município tem cerca de 650 mil habitantes, faz divisa com São Paulo e outras cidades do Grande $\mathrm{ABC}$ e não possui meios locais de comunicação eletrônica, de penetração relevante, junto à sua população. A comunidade recebe, via televisão e rádio, os sinais das emissoras da capital São Paulo. Assim, o cidadão andreense tem mais condições, por exem- plo, de acompanhar o cotidiano da Câmara de São Paulo do que da sua própria cidade.

Recorrer aos meios de comunicação sediados na capital para comunicar ações do governo municipal, embora às vezes isso seja necessário, é uma prática quase inviável em função dos custos que envolve. A tabela de preços praticada pelos meios de comunicação é a da região metropolitana como um todo e a relação custo-benefício não se sustenta. Em suma, paga-se um alto preço para comunicar-se com a capital e demais municípios da região metropolitana quando, na verdade, o público-alvo é apenas o morador de Santo André.

Com relação aos meios de comunicação de Santo André, tem-se o predomínio da mídia impressa: um jornal diário, algumas revistas mensais e inúmeros pequenos jornais semanais e mensais. Sobre o jornal diário, apesar de ser um poderoso meio junto aos formadores de opinião, tem uma penetração pequena sobre o universo total de moradores. O mesmo vale para as revistas mensais. Quanto aos jornais semanais e mensais, com pouquíssimas exceções, os dados de circulação e tiragem são difíceis de precisar, pois nem sempre as informações fornecidas por eles são confiáveis.

Os meios de comunicação eletrônica resumem-se a um canal a cabo, uma rádio AM, que não está entre as mais ouvidas, e algumas rádios comunitárias. Essas últimas seriam veículos interessantes, mas sofrem com problemas de limitação de recursos e mesmo com as investidas da fiscalização. De qualquer maneira, a administração municipal procura apoiar o movimento dessas rádios. Pelo menos, as efetivamente comunitárias. 


\section{COMUNICAÇÃO A SERVIÇO DO MUNICÍPIO}

A Prefeitura de Santo André, bem como a imensa maioria dos grandes municípios do País, enfrenta severas limitações financeiras e orçamentárias. A demanda por serviços públicos é, invariavelmente, muito maior que os recursos financeiros para atendê-la. Assim, a verba do Núcleo de comunicação da prefeitura, destinada para suprir as suas necessidades - que são as de divulgar, comunicar ou publicizar - além de todos os serviços e ações do governo, está longe de ser suficiente. Mas a limitação de dinheiro, mesmo sendo uma agravante, é um problema que permeia todo o corpo público. É um erro achar que bastaria ter mais recursos para a comunicação que todo o resto estaria resolvido. É preciso eleger prioridades, hierarquizar e otimizar recursos, ainda mais por serem públicos.

Aqueles que estão fora de uma administração pública, como a de Santo André, não têm idéia de suas necessidades comunicacionais. Arrisco-me a dizer que inclusive o núcleo dirigente do governo, bem como a nossa própria coordenação de comunicação, não conseguem dimensioná-la com exatidão.

São 14 secretarias ou coordenadorias, cinco autarquias ou fundações, todas subdivididas em departamentos e gerências, com demandas à área de comunicação. Solicitações que vão desde a divulgação de shows, palestras, cursos até obras, programas sociais, serviços de saúde e muitos, muitos outros.

O cotidiano, então, é tomado na condução de todas essas ações. Pelo menos as possíveis de serem levadas adiante, pois muitas perdem-se ou são minimizadas diante das prioridades definidas. Além disso, gastos com comunicação costumam ser criticados por parte da população ou da oposição política da cidade. Trata-se de uma postura discutível. Curiosamente, pesquisas internas apontaram que uma das reclamações dos moradores é o desconhecimento das atividades da Prefeitura de Santo André, bem como deficiências em sua divulgação.

Assim sendo, respeitando-se o bom senso, os recursos gastos em comunicação são absolutamente fundamentais para o funcionamento da máquina pública. Por exemplo, um programa social para ser utilizado precisa ser conhecido, o mesmo para um equipamento público qualquer. Seu desconhecimento significa, na maioria das vezes, subutilização e aí sim teremos desperdício de recursos públicos. Importante é deixar claro que não estamos tratando de autopromoção do governo, prática que deve ser sempre repudiada. Infelizmente, sabemos que isso acontece muito no Brasil, através da chamada publicidade oficial.

Um ponto a ser lembrado na produção da comunicação de uma instituição pública do porte de uma grande prefeitura, até pelo papel central que ocupa, é a relação governo e agência de publicidade. Com a necessidade de produção de material em grande volume, diversificado e com agilidade, costuma-se optar pela contratação de uma agência para responder a tais serviços. Aqui encontramos um fator crucial que pode colocar em xeque o trabalho da comunicação municipal.

No geral, as agências de comunicação costumam adotar para os órgãos públicos os mesmos conceitos de trabalho que norteiam as ações da iniciativa privada. 
E, pelas características das agências, o conceito de comunicação com o qual trabalham é aquele de perfil funcionalista, calcado na relação direta de emissor/receptor, desconsiderando o processo comunicacional em suas várias interfaces. Busca-se apenas atingir o maior número possível de pessoas, de modo padronizado. O receptor, nesta situação, surge como integrante de uma imensa massa uniforme, sem peculiaridades, sem desejos e aspirações.

Há, evidentemente, um campo de tensão entre uma proposta de comunicação mais complexa, interativa e enraizada na diversidade e uma outra, convencional. O confronto, inclusive, não é dualista: administração municipal versus agência de publicidade. Pois, no interior do governo, há o sentimento de que a comunicação pública e oficial deve seguir parâmetros tendo como baliza os interesses de mercado.

Dado esse quadro, deve-se alcançar um proposta única que contenha elementos destes vários campos de tensão. Consensualizar diferentes posturas, de modo que se mantenha uma linha mestra claramente definida, deve ser o caminho delineado numa proposta de política comunicacional para a Prefeitura de Santo André. E é isso que está sendo procurado.

Essa linha mestra deve levar em conta aspectos imprescindíveis em sua concepção. Deve enxergar, vale lembrar mais uma vez, a comunicação como processo dialógico e dialético.
Atentar para o receptor, para suas características e aspirações, trazendo-o para o debate e tornando-o personagem da História da sua cidade.

Nesta situação, a administração municipal precisa relacionar-se com a população a partir de referenciais como identidade, cidadania e participação popular.

Como aponta Maria Aparecida Baccega, quando trata da questão do receptor, "compete ao discurso da comunicação procurar os 'fios ideológicos' (expressão de Mikhail Bakthin) com os quais conduzirá a inter-relação entre eles, tecendo-se. Sua trama implica a dialogicidade, presente na polifonia, numa manifestação das relações macroestruturais com a vida cotidiana" ${ }^{2}$.

Descobrir o funcionamento dessa teia informacional não é fácil. $\mathrm{E}$ é tanto mais difícil quanto mais complexa for a comunidade envolvida. No entanto, uma administração sensível às necessidades dos cidadãos deve romper as barreiras e lançarse nesta nova proposta. Assim deve ser encarado o desafio em Santo André. Porque, a exemplo de tantos programas sociais que a administração da cidade sustenta, a comunicação será mais eficiente à medida que carregar consigo a idéia de inclusão.

\section{COMUNICAR PARA INCLUIR}

Um caso bem-sucedido dessa linha de comunicação de inclusão é o projeto 
Santo André - cidade futuro, que vem sendo desenvolvido há cerca de três anos pela administração municipal. Trata-se de um planejamento da cidade para as próximas duas décadas, orientando seu desenvolvimento conforme aspirações coletadas junto à própria população. $\mathrm{O}$ trabalho já elegeu uma série de prerrogativas que apontam para um município melhor. Numa conferência realizada em abril, com mais de 400 delegados escolhidos pela comunidade, foi elaborada a Carta de Santo André. Uma nova rodada de discussões será reiniciada e o processo vai prosseguir até à próxima conferência, que deverá se realizar em abril de 2001. É um projeto, pela sua própria concepção, que se renova a cada dia e não tem data para terminar. Cabe ao governo municipal, em conjunto com a sociedade civil, colocar em prática as diretrizes tiradas da conferência. Dada a complexidade da sua operação, o Cidade futuro não é um projeto conduzido pelo Núcleo de Comunicação da Prefeitura de Santo André, mas optouse por dotá-lo de uma estrutura própria. Demonstração de que o governo como um todo é agente de comunicação, papel que não cabe somente à área específica do Núcleo de Comunicação.

Uma outra iniciativa que deu resultados expressivos e provocou interação no município foi um concurso, no qual a população pintaria um mapa estilizado da cidade. O mapa acabou sendo utilizado nas salas de aula da rede municipal de ensino e despertou, nos estudantes, a curiosidade de conhecer melhor a cidade onde vivem. Muitos desconheciam aspectos importantes das localidades retratadas, como a histórica Vila de Paranapiacaba, patrimônio nacional, pertencente a Santo André.

$\mathrm{O}$ projeto Cidade futuro assim como a iniciativa do mapa da cidade são exemplos de que se pode estimular ações menos ortodoxas de comunicação, cujos resultados são bem mais satisfatórios do que os tradicionais. Claro que para divulgar tais iniciativas foram utilizados alguns métodos de propaganda comuns, como anúncios nos jornais. No entanto, estes estiveram longe de ser determinantes no sucesso das empreitadas.

Democratizar a informação e abrir-se ao debate só vem contribuir para que a administração municipal desenvolva seu papel de mediadora entre os interesses públicos e as instâncias políticas. E mais, que essa mediação seja feita com transparência. Não devemos nos esquecer de que o governo foi eleito a partir de seu programa, de suas propostas, que estão em consonância com os anseios da maioria da população. Nada mais coerente, portanto, que a população saiba o que está acontecendo neste seu território.

Não há receita, no entanto, para se traçar políticas de comunicação. Menos ainda para políticas públicas de comunicação. É um jogo de acertos e de erros, jogado ao longo dos tempos. O imediatismo, por causa de sua ação devastadora, é adversário bastante presente. Caso não se tenha convicção nos rumos tomados, 
as expectativas por resultados no curtíssimo prazo tendem a colocar em risco qualquer ação comunicativa mais profunda, que finque raízes no tecido social e não se perca no dia-a-dia. Este é o desafio que se propõe em Santo André.
Afinal, como lembra Jesus MartínBarbero: "a cidade já não é só um 'espaço ocupado' ou construído, mas é também um espaço comunicacional, que conecta entre si seus diversos territórios e os conecta com o mundo" ${ }^{3}$.
Resumo: O depoimento do gestor e coordenador de comunicação da prefeitura de Santo André refere-se ao trabalho que vem desenvolvendo na prefeitura, salientando a importância de um projeto de comunicação que interaja com a população. Ele ressalta especificidades da comunicação na administração pública e destaca os desafios da implantação de um projeto comunicacional que inclua a comunidade como parte ativa e atuante, a exemplo do que vem sendo feito em Santo André.

Palavras-chave: gestão da comunicação, Santo André, cidadania, administração pública, municipio, cidade
Abstract: The interview given by the Santo André communications manager and coordinator refers to the work that has been being carried out at the city hall, stressing the importance of a communication project that interacts with the population. It emphasizes the public administration communication specificities and highlights the challenges to implant a communicational project that includes the community as an active and performing part, following the example of what is done in Santo André.

Key words: communication management, Santo André, citizenship, public administration, municipality, city 